\title{
PELAKSANAAN BANTUAN HUKUM PADA PERKARA PIDANA OLEH PERHIMPUNAN BANTUAN HUKUM DAN HAK ASASI MANUSIA INDONESIA SUMATERA BARAT DI KOTA PADANG*
}

\author{
Febtrina Sari \\ Pascasarjana Fakultas Hukum, Universitas Andalas Padang \\ e-mail: febtrina.sr@gmail.com
}

\begin{abstract}
Indonesia is a nation based on the rule of law (State of Law) in accordance with Article 1 paragraph (3) of the 1945 Constitution of Indonesia (UUD 1945). State of Law rests on protection of human rights, non-discrimination, and equality before the law, which means that the state guarantees equality before the law by stipulating that everybody has a right to equal standing before the law and access to justice. Law No. 16 Year 2011 concerning Legal Aid (Legal Aid Law) is a manifestation of State of Law, which implementation is delegated to the Ministry of Law and Human Rights of the Republic of Indonesia (Regional Office of Law and Human Rights or 'Kanwil Hukum dan HAM') in cooperation with Legal Aid Organizations ('OBH'). The legal aid concept is a provision of state funding for the poor in order to guarantee their access to justice. This article looks at the implementation of legal aid for the poor by PBHI Sumbar in criminal cases within the Jurisdiction of State Court Class 1A Padang using juridical-sociological research method. PBHI Sumbar provides legal aid for the poor based on the Legal Aid Law, but provides exceptions for certain cases, namely corruption, environmental crimes, human rights abuses, and morality or sexrelated crimes. The exceptions are subjective and inconsistent that restricts access to legal aid. In general, PBHI Sumbar provides legal aid in common criminal cases in a well-implemented manner, but in special criminal cases, its role is below optimal.
\end{abstract}

Keywords : Legal Aid, Poor Communities, Legal Aid Organizations.

\begin{abstract}
Abstrak
Indonesia adalah negara hukum sesuai dengan Pasal 1 ayat (3) Undang-undang Dasar Republik Indonesia tahun 1945 (UUD 1945). Negara Hukum berdasar pada perlindungan hak asasi manusia, non deskriminatif dan menjamin adanya hak perlakuan sama di hadapan hukum (equality before the law), yang bermakna bahwa negara menjamin persamaan kedudukan hukum bagi setiap orang dengan mengatur hak perlakuan sama di depan hukum dan jaminan akses terhadap keadilan. UU Nomor 16 tahun 2011 tentang Bantuan Hukum (UU Bantuan Hukum) adalah pelaksanaan Negara Hukum tersebut yang memandatkan penyelenggaraannya pada Kementerian Hukum dan HAM RI (Kanwil Hukum dan HAM) dengan bekerja sama dengan Organisasi Bantuan Hukum $(\mathrm{OBH})$. Konsep Bantuan Hukum sendiri adalah pembiayaan negara bagi masyarakat miskin dalam rangka jaminan akses terhadap keadilan. Artikel ini melihat pelaksanaan bantuan hukum pada perkara-perkara Pidana oleh PBHI Sumbar sebagai mitra OBH di Wilayah Hukum Pengadilan Negeri Klas 1 A Padang dengan metode penelitian yuridis sosiologis. PBHI Sumbar melaksanakan pemberian bantuan hukum kepada orang miskin berdasarkan UU Bantuan Hukum, namun memberlakukan pengecualian pada kasus-kasus tertentu, yaitu Korupsi, kejahatan lingkungan, pelanggaran HAM dan kejahatan asusila. Pengecualian tersebut bersifat subjektif dan inkonsisten sehingga membatasi akses bantuan hukum.
\end{abstract}

Kata Kunci : Bantuan Hukum, Masyarakat Miskin, Organisasi Bantuan Hukum.

\footnotetext{
* Naskah diterima: 27 Juli 2018, direvisi: 08 September 2018, disetujui untuk terbit: 23 September 2018
} 


\section{PENDAHULUAN}

Hak masyarakat miskin untuk mendapatkan bantuan hukum oleh advokat secara cuma-cuma (pro bono publico) adalah penjabaran dari prinsip persamaan hak di hadapan hukum (Winarta, 2000: 50). Faktanya, penggunaan jasa advokat memang membutuhkan biaya dan tidak mungkin bagi orang miskin untuk mengakses jasa tersebut. Untuk mengatasi permasalahan ini, maka bantuan hukum yang bisa diakses oleh orang miskin menjadi penting.

Pada tanggal 2 November 2011 telah diundangkan Undang-Undang Nomor 16 tahun 2011 tentang Bantuan Hukum (Selanjutnya disebut UU Bantuan Hukum). UU Bantuan Hukum lahir dengan semangat memenuhi tanggung jawab negara atas bantuan hukum bagi masyarakat miskin secara cuma-cuma untuk akses terhadap keadilan bagi seluruh masyarakat Indonesia. Hal ini bisa ditemukan dalam Naskah Akademik UU Bantuan Hukum pada bagian tinjuan sosiologisnya yang menyebutkan bahwa urgensi lahirnya UU ini adalah untuk mengatasi ketimpangan pelayanan pendampingan hukum terutama bagi populasi masyarakat miskin Indonesia dalam rangka akses terhadap keadilan (acces to justice) dimana peran Lembaga Bantuan Hukum menjadi penting (Mukianto, 2017: 119).

Secara normatif, pengertian bantuan hukum sendiri ditemukan dalam pasal 1 angka 1 UU Bantuan Hukum menyatakan bahwa, "Bantuan Hukum adalah jasa hukum yang diberikan oleh Pemberi Bantuan Hukum secara cuma-cuma kepada Penerima Bantuan Hukum". Pengertian bantuan hukum diatas selaras dengan konsep bantuan hukum, yaitu bahwa bantuan hukum adalah pembiayaan secara cuma-cuma oleh Negara kepada masyarakat miskin yang berhadapan dengan hukum. Pemberian bantuan hukum sendiri dilaksanakan oleh organisasi kemasyarakatan atau Lembaga bantuan hukum, yang memberikan layanan bantuan hukum kepada masyarakat miskin.

Selanjutnya, pemberian bantuan hukum sesuai dengan UU bantuan hukum meliputi bantuan hukum pada kasus-kasus pidana, perdata, tata usaha negara dan juga jasa non litigasi. UU Bantuan hukum juga menjelaskan tentang tahapan pemberian layanan bantuan hukum kepada masyarakat miskin, yaitu; tahap menjalankan kuasa, mendampingi, mewakili, membela dan/atau melakukan tindakan hukum lain yang diperlukan.

Dalam konteks Sumatera Barat, masyarakat miskin berdasarkan data Badan Pusat Statistik tahun 2016 adalah berjumlah 371.055 jiwa. Kota Padang menempati peringkat pertama penduduk miskin yaitu berjumlah 43.056 jiwa. Berdasarkan data tersebut maka dari jumlah populasi warga kota Padang sebanyak 902.413 orang, terdapat 43.056 penduduk miskin, yang perlu mendapat perhatian di segala bidang kehidupan, termasuk di bidang hukum, terutama hak untuk mendapat bantuan hukum. 
Febtrina Sari: Pelaksanaan Bantuan Hukum Pada Perkara Pidana...

Kota Padang adalah ibukota Provinsi Sumatera Barat yang terletak di pantai barat pulau Sumatera, luas Kota Padang adalah $694,96 \mathrm{~km} 2$ atau setara dengan 1,65 persen dari luas Provinsi Sumatera Barat (Bappeda Padang, 2017: 2). Kota Padang adalah kota pusat pemerintahan, pendidikan, dan perekonomian. Hal ini melahirkan potensi lahirnya persoalanpersoalan hukum di tingkat warga, setidaknya dalam aspek kriminalitas. Direktorat Reserse Kriminal Umum Kepolisian Daerah Sumatera Barat menyebutkan bahwa kota Padang menduduki peringkat pertama terkait pidana umum. Kepolisian Resort Kota Padang menunjukkan bahwa jumlah perkara pidana yang masuk di Polresta sepanjang tahun 2016 ini adalah berjumlah 6.463 kasus. Data ini menunjukkan bahwa, dari segi kuantitas, Kota Padang memiliki tingkat kejahatan atau tingkat kriminalitas paling tinggi dibandingkan dengan 18 kabupaten/kota lain di Provinsi Sumatera Barat. Berdasarkan besarnya jumlah perkara pidana yang masuk di Polresta, serta dengan adanya 43.056 penduduk miskin di Kota Padang, maka wilayah Kota Padang menarik untuk menjadi tempat penelitian mengenai bantuan hukum bagi orang atau kelompok orang miskin dalam perkara pidana demi terselenggaranya proses hukum yang adil.

Provinsi Sumatera Barat sendiri mempunyai 5 (lima) lembaga bantuan hukum atau organisasi kemasyarakatan yang memiliki akreditasi sebagai pemberi bantuan hukum, yang tertuang dalam
Keputusan Menteri Hukum dan HAM Republik Indonesia Nomor M.HH01.HN.03.03 Tahun 2016 tentang Lembaga/Organisasi Bantuan Hukum Yang Lulus Verifikasi Dan Akreditasi Sebagai Pemberi Bantuan Hukum Periode Tahun 2016 S.D. 2018, masing-masing yaitu; Perhimpunan Advokasi Hak Asasi Manusia Sumatera Barat (PAHAM Sumbar), Perkumpulan Kantor Hukum Fiat Justitia, Perhimpunan Bantuan Hukum Dan HAM Indonesia wilayah Sumbar (PBHI Sumbar), Yayasan Lembaga Bantuan Hukum Indonesia (YLBHI) Kantor LBH Padang) dan Pos Bantuan Hukum Advokat Indonesia (POSBAKUMADIN Koto Baru Solok).

Berdasarkan UU Bantuan Hukum dan keputusan Menteri Kementerian Hukum dan HAM tentang akreditasi lembaga/OBH tersebut diatas, maka kegiatan penyelenggaraan bantuan hukum di Sumatera Barat diselenggarakan oleh Kementerian Hukum dan HAM Kantor Wilayah Sumatera Barat bekerja sama dengan 5 OBH tersebut, yang selanjutnya dituangkan dalam suatu perjanjian kerja sama (Memorandum of Understanding (MoU)).

Tulisan ini akan fokus pada pelaksanaan bantuan hukum pada perkara-perkara pidana di kota Padang. Dalam konteks tersebut maka penulis memilih Perhimpunan Bantuan Hukum Dan HAM Indonesia wilayah Sumbar (selanjutnya disebut PBHI Sumbar) dengan berlandaskan pada alasan PBHI Sumbar sebagai salah satu OBH yang banyak menangani perkara pidana di kota 
Padang atau pada wilayah Hukum Pengadilan Negeri Klas I A Padang. Jika dibandingkan dengan OBH lain, misalnya YLBHI Kantor LBH Padang (selanjutnya disebut LBH Padang) lebih banyak menangani kasus perkara perdata, begitupun Fiat Justisia yang banyak menangaani kasus perkara pidana di Wilayah Hukum Pengadilan Negeri Pasaman Barat, dan terakhir PAHAM Sumbar telah ada penelitian sejenis terkait bantuan hukum. Oleh sebab itu pilihan pada PBHI Sumbar menjadi relevan untuk melihat pelaksanaan bantuan hukum bagi masyarakat miskin di Kota Padang.

Bantuan hukum yang telah diberikan oleh PBHI dalam kurun waktu 2016 sendiri adalah sebanyak 7 kasus pidana dengan nomor perkara yang sudah inkracht sebagai berikut: 745 / Pid.Sus / 2015/PN.Pdg,PDM-11 /LB.BSG/03/2016, PDM-258/Euh.2/Pdang/04/2016, PDM11/Euh.2/Pdang/07/2016,PDM-

374/Epp.2/Pdang/05/2016,

PDM-

14/Epp.2/Pdang/08/2016,

PDM-

12/LB.BSG/05/2016,

PDM-

373/Euh.2/Pdang/05/2016,

PDM-

12/Euh.2/Pdang/08/2016. Tulisan akan memilih Perkara-perkara pidana tersebut diatas sebagai objek penelitian studi kasus. Pemilihan kasus-kasus akan dipilah lagi pada dua kategori, yaitu kasus pidana khusus dan pidana umum dengan terlebih dahulu melihat ketersediaan data-data yang ada, baik data sekunder maupun data primer.

Kasus-kasus pidana dipilih dengan pertimbangan bahwa aspek bantuan hukum berperan menciptakan keadilan, menegakkan HAM, dan equality before the law, serta dalam mencapai due process of law serta dengan adanya pembaharuan secara normatif tentang bantuan hukum, tentu membawa perubahan dalam implementasinya, tentu menjadikan kewajiban pemberian bantuan hukum menjadi hal penting untuk dapat dilaksanakan secara efektif.

\section{METODE PENELITIAN}

Penelitian ini menggunakan metode pendekatan penelitian yuridis sosiologis, yaitu melihat norma hukum dengan faktafakta empirik yang ditemui dari masalah penelitian (Sunggono, 2006: 27). Penelitian menggunakan pendekatan kualitatif yang bersifat deskriptif analitik yaitu tipe penelitian yang bertujuan menggambarkan suatu keadaan tertentu yang terjadi di lapangan (Maleong, 1991; 103). Dalam hal ini berkaitan pemberian bantuan hukum terhadap masyarakat miskin dalam perkara-perkara pidana oleh PBHI Sumbar di Kota Padang atau pada Wilayah Hukum Pengadilan Negeri Klas I A Padang.

\section{HASIL DAN PEMBAHASAN}

\section{Konsep dan Standar Bantuan Hukum}

Konsep bantuan hukum telah berkembang dan lebih dipertegas kepada pemberian bantuan hukum bagi orang atau kalangan orang yang tergolong miskin. Dalam pengertian luas (umum), bantuan hukum adalah membantu golongan yang tidak mampu dalam bidang hukum (Nasution, 1982: 1). Selanjutnya, bantuan hukum dari segi 
Febtrina Sari: Pelaksanaan Bantuan Hukum Pada Perkara Pidana...

realitas sosialnya dapat dilihat dalam tiga konsep bantuan hukum, yakni konsep bantuan hukum tradisional, konsep bantuan hukum konstitusional, dan konsep bantuan hukum struktural (Anwar dan Adang, 2009: 246).

\section{Konsep Bantuan Hukum Tradisonal}

Bantuan hukum dalam arti tradisional bersifat legal formal dan pasif serta berbasis pada pemberian bantuan kepada masyarakat miskin secara individual (Anwar dan Adang, 2009: 246-247). Konsep ini adalah konsep pemberian bantuan hukum secara pro bono publico (Winarta, 2009: 21) Atau pemberian hukum secara cuma-cuma (Ishaq, 2010: 13)

\section{Konsep Bantuan Hukum \\ Konstitusional}

Bantuan Hukum dalam arti Konstitusional muncul dengan latar bahwa bantuan hukum untuk masyarakat miskin adalah dalam konteks usaha dan tujuan yang luas. Misalnya penyadaran hak-hak masyarakat miskin sebagai subjek hukum, penegakan hak asasi manusia dalam konteks negara hukum. Karakter bantuan hukum konstitusional ini bersifat aktif, yaitu pemberian bantuan hukum secara kolektif kepada masyarakat miskin.

3. Konsep Bantuan Hukum Struktural

Konsep Bantuan Hukum Struktural
adalah kegiatan yang bertujuan
menciptakan kondisi-kondisi bagi terwujudnya hukum yang mampu mengubah struktur yang timpang menuju ke arah struktural yang lebih adil, tempat peraturan hukum dan pelaksanaannya dapat menjamin persamaan kedudukan baik di lapangan hukum atau politik (Anwar dan Adang, 2009: 246-247)

Konsep bantuan hukum terbagi dalam tiga sifat/karakter, yaitu bantuan hukum dalam arti tradisional, konstitusional, dan struktural. Karakter-karakter bantuan hukum tersebut lahir dari latar belakangnya sendiri. Adapun latar belakang tersebut adalah; Konsep bantuan hukum tradisional muncul dari latar bahwa sistem bantuan hukum berbasis individual, dan belum berkembang menjadi bantuan hukum berbasis kolektif seperti halnya prosedur class action. Konsep bantuan hukum konstitusional di latar belakangi oleh usaha untuk mewujudkan negara hukum yang berlandaskan pada prinsip-prinsip demokrasi dan Hak Asasi Manusia.

Indonesia adalah negara hukum sebagaimana tercantum dalam Pasal 1 ayat (3) UUD 1945. Dalam negara hukum, negara mengakui dan melindungi hak asasi manusia setiap individu tanpa membedakan latar belakangnya sehingga semua orang memiliki hak untuk mendapatkan perlakuan yang sama di hadapan hukum, asas persamaan di hadapan hukum, diatur dalam Pasal 27 ayat (1) UUD 1945 yang menyatakan: Segala warga negara bersamaan kedudukannya di dalam hukum dan pemerintahan dan wajib menjunjung hukum dan pemerintahan itu dengan tidak ada kecualinya. Sebagai konsekuensi dari negara hukum, hak untuk mendapatkan bantuan hukum harus di berikan oleh 
negara dan itu merupakan jaminan perlindungan terhadap hak asasi manusia.

UU Bantuan Hukum memastikan pemenuhan hak masyarakat miskin untuk akses terhadap keadilan (access to justice) sebagai perwujudan tanggungjawab negara. Oleh sebab itu, konsep bantuan hukum dalam UU Bantuan Hukum adalah pembiayaan pemberian bantuan hukum secara cuma-cuma oleh Negara kepada masyarakat miskin.

Selanjutnya, dalam pelaksanaan pemberian bantuan hukum tersebut harus mengacu kepada Standar Bantuan Hukum. Pasal 1 angka 5 UU Bantuan Hukum menyebutkan, standar bantuan hukum adalah pedoman pelaksanaan pemberian Bantuan Hukum yang di tetapkan oleh Menteri. Berdasarkan Peraturan Menteri Hukum dan HAM Nomor 10 tahun 2015 tentang Peraturan Pelaksanaan Peraturan Pemerintah Nomor 42 tahun 2013 tentang Syarat dan Tata Cara Pemberian Bantua Hukum dan Penyaluran Dana Bantuan Hukum sebagaimana telah diubah dengan Peraturan Menteri Hukum dan HAM Nomor 63 tahun 2016 tentang Perubahan Atas Peraturan Menteri Hukum dan HAM Nomor 10 tahun 2015 tentang Peraturan Pelaksanaan Peraturan Pemerintah Nomor 42 tahun 2013 tentang Syarat dan Tata Cara Pemberian Bantuan Hukum dan Penyaluran Dana Bantuan Hukum, pada Pasal 2 ayat (1) dan ayat (2) menyebutkan:

(1) Pemberian Bantuan Hukum harus memenuhi Standar Bantuan Hukum.
(2) Standar Bantuan Hukum sebagaimana dimaksud pada ayat (1) dilaksanakan untuk penanganan:

a) Bantuan Hukum secara litigasi; dan

b) Bantuan Hukum secara nonlitigasi.

Standar bantuan hukum secara litigasi dilaksanakan dalam penanganan perkara, pidana, perdata dan tata usaha negara. Bantuan Hukum secara litigasi dalam penanganan perkara pidana diberikan kepada penerima bantuan hukum yang berstatus sebagai: a) tersangka; b) terdakwa; atau c) terpidana yang mengajukan upaya hukum biasa atau upaya hukum luar biasa. Bantuan hukum secara litigasi ini diberikan pada tahapan; a) pendampingan dan/atau menjalankan kuasa yang dimulai dari tingkat; penyidikan dan penuntutan; b) pendampingan dan/atau menjalankan kuasa dalam proses pemeriksaan di persidangan dimulai dari; tingkat pertama; upaya hukum biasa;dan/atau; upaya hukum luar biasa.

Standar bantuan hukum secara nonlitigasi dilaksanakan oleh pemberi bantuan hukum meliputi; penyuluh hukum; konsultasi hukum; investigasi kasus, baik secara elektronik maupun secara nonelektronik; penelitian hukum; mediasi; negoisasi; pemberdayaan masyarakat; pendampingan di luar pengadilan; dan/atau drafting dokumen hukum. 
Febtrina Sari: Pelaksanaan Bantuan Hukum Pada Perkara Pidana...

\section{Pelaksanaan Bantuan Hukum}

Para pihak bantuan hukum yang disebutkan oleh UU Bantuan Hukum terdiri dari; pertama, penerima bantuan hukum, yaitu masyarakat miskin, baik secara kelompok maupun perorangan, kedua, Pemberi Bantuan Hukum, yaitu Organisasi Bantuan Hukum yang telah terverifikasi dan terakreditasi, ketiga, penyelenggara bantuan hukum, yaitu Kementerian Hukum dan Hak Asasi Manusia Republik Indonesia cq Badan Pembinaan Hukum Nasional. Para pihak yang kemudian disebut oleh UU Bantuan Hukum ini sebagai pihak-pihak yang menyelenggarakan bantuan hukum oleh Menteri Hukum dan HAM, yang dilaksanakan oleh Pemberi Bantuan Hukum.

Penyelenggaraan bantuan hukum di Sumatera Barat sendiri dilaksanakan oleh Kantor Wilayah Kementerian Hukum dan HAM Sumatera Barat, yang setiap awal tahunnya diawali dengan terbitnya Surat Edaran dari Kepala Badan Pembinaan Hukum Nasional (selanjutnya disebut dengan BPHN). Surat Edaran ini menjadi acuan bagi daerah dan pemberi bantuan hukum /OBH dalam melaksanakan bantuan hukum. Adapun ruang lingkup surat edaran ini meliputi mekanisme pelaksanaan bantuan hukum yang harus dilakukan oleh Panitia Pengawas Pusat, Panitia Pengawas Daerah dan OBH. Dengan terbitnya surat edaran tersebut, pihak Kantor Wilayah Kementerian Hukum dan HAM Sumatera Barat segera menindaklanjuti dengan penandatanganan kontrak perjanjian kerja sama antara
Kepala Kantor Wilayah Kementerian Hukum dan HAM Sumatera Barat dengan Direktur OBH di Provinsi Sumatera Barat. Selain itu, dalam hal penyelenggaraan bantuan hukum sebelum terbitnya Surat Edaran oleh Kepala BPHN, tidak menutup kewajiban $\mathrm{OBH}$ untuk melaksanakan program bantuan hukum terhadap masyarakat miskin sesuai UU Bantuan Hukum.

Pada tahun 2016, BPHN telah memberikan anggaran dana bantuan hukum kepada OBH-OBH di Sumatera Barat sebesar Rp. 453.350.000-, (empat ratus lima puluh tiga juta tiga ratus lima puluh ribu rupiah). Dana tersebut dibagi atas dua peruntukan, yaitu litigasi, termasuk perkara pidana, perdata dan tata usaha negara dan non litigasi, untuk perkara litigasi dianggarkan sebesar Rp. 400.000.000,- (empat ratus juta rupiah), sedangkan untuk non litigasi dianggarkan sebanyak Rp. 53.350.000,- (lima puluh tiga juta tiga ratus lima puluh ribu rupiah). Anggaran untuk litigasi sendiri yang diberikan kepada 5 (lima) $\mathrm{OBH}$, yakni sebesar Rp. 80.000.000,-/per-OBH. Sesuai Keputusan Menteri Hukum dan HAM Nomor M.HH.-01.HN. 03.03 Tahun 2015 tentang Besaran Biaya Bantuan Hukum Litigasi dan Non Litigasi, dengan satuan biaya bantuan hukum litigasi per total biaya perkara sejumlah Rp. 5.000.000,- (lima juta rupiah).

Pada tingkat penanganan kasus pidana secara litigasi, PBHI Sumbar memberikan bantuan hukum merujuk pada kriteria penerima bantuan hukum 
berdasarkan UU Bantuan Hukum, yaitu individu yang tidak mampu atau miskin selain itu juga merujuk kepada perkaraperkara yang telah ditetapkan organisasi untuk ditolak, yaitu empat kasus pengecualian, sebagai berikut; pelaku pelanggaran HAM, korupsi, kejahatan asusila yang dilakukan orang dewasa, dan kejahatan lingkungan.

Adapun proses penanganan perkara tersebut dibagi atas tiga tahap, yaitu; tahap pertama, permohonan bantuan hukum oleh penerima bantuan hukum kepada kantor PBHI Sumbar. Proses ini biasanya dilaksanakan secara langsung melalui wawancara tatap muka antara pemohon dengan pengacara PBHI Sumbar. Wawancara tersebut terkait dengan pembahasan awal tentang kasus pidana yang menjerat pemohon, dan untuk menilai apakah pemohon tersebut layak atau tidak menerima bantuan hukum.

Dalam penilaiannya, PBHI Sumbar mensyaratkan dokumen surat keterangan tindak mampu dari kelurahan setempat sebagai syarat administratif. Syarat administratif tersebut tidak bersifat mutlak, yang penilaian kelayakan tersebut ditambah dari penilaian wawancara tatap muka dan observasi terhadap pemohon bantuan hukum, misalnya salah satu kriteria observasinya adalah apakah calon penerima bantuan hukum tersebut memakai kendaraan pribadi berupa mobil atau tidak. PBHI sendiri belum mempunyai metoda observasi yang baku untuk menilai kelayakan pemohon bantuan hukum. Dalam hal tenggat waktu penerimaan permohonan bantuan hukum, PBHI Sumbar memberikan waktu tenggat tiga (3) hari kerja untuk memutuskan menerima atau menolak permohonan tersebut. Penerimaan permohonan dan atau penolakan permohonan disampaikan secara lisan dengan alasan-alasan menolak atau menerima permohonan.

Tahap kedua; Gelar Perkara. Calon penerima bantuan hukum setelah memberikan permohonan kepada PBHI Sumbar seperti pada tahap pertama yang disebutkan di atas, selanjutnya, Pengacara (tim pengacara) PBHI Sumbar mengadakan rapat gelar perkara. Rapat tersebut berfungsi untuk menerima atau menolak pendaftaran calon penerima bantuan hukum berdasarkan kriteria hukum tentang penerima bantuan hukum, yaitu masyarakat miskin. Selain kriteria masyarakat miskin, PBHI Sumbar memiliki kriteria khusus, yaitu pengecualian penanganan kasus-kasus oleh PBHI Sumbar berdasarkan alasan bertentangan dengan visi-misi organisasinya. Kasus-kasus tersebut adalah; Kasus-Kasus Pidana Korupsi yang termuat dalam Undang-Undang Nomor 31 Tahun 1999 tentang Pemberantasan Tindak Pidana Korupsi; Kasus-kasus Pidana bagi pelaku terhadap pelanggaran HAM yang termuat dalam UndangUndang 39 tahun 1999 tentang Hak Asasi Manusia; Kasus-Kasus kejahatan lingkungan, misalnya kasus illegal logging dan illegal mining; Kasus-Kasus kejahatan seksual yang dilakukan oleh orang dewasa, yaitu pidana pencabulan dan pemerkosaan. Pada kasus kejahatan 
Febtrina Sari: Pelaksanaan Bantuan Hukum Pada Perkara Pidana...

seksual ini dikecualikan pada kasus-kasus yang melibatkan anak sebagai pelaku (tersangka) dengan pertimbangan untuk melaksanakan perlindungan anak yang bermasalah dengan hukum berdasarkan Undang-Undang Nomor 35 tahun 2014 tentang Perlindungan Anak.

PBHI Sumbar menyebutkan bahwa pengecualian pemberian bantuan hukum pada empat jenis kasus pidana diatas, selain berlandasakan visi misi organisasi juga terkait dengan kebebasan advokat untuk menerima atau menolak kasus karena bertentangan dengan hati nurani, yaitu sebagaimana diatur dalam Pasal 3 huruf a Kode Etik Advokat Indonesia (KEAI), yaitu ;

"Advokat dapat menolak untuk memberi nasihat dan bantuan hukum kepada setiap orang yang memerlukan jasa dan atau bantuan hukum dengan pertimbangan oleh karena tidak sesuai dengan keahliannya dan bertentangan dengan hati nuraninya, tetapi tidak dapat menolak dengan alasan karena perbedaan agama, kepercayaan, suku, keturunan, jenis kelamin, keyakinan politik dan kedudukan sosialnya."

Dalam praktiknya, PBHI Sumbar menerapkan pengecualian penanganan empat jenis kasus pidana tersebut secara tidak konsisten, karena masih dimungkinkannya pemberian konsultasi hukum pada penerima bantuan hukum yang dijerat pada empat jenis kasus pidana tersebut, walaupun tidak dilanjutkan dengan pemberian kuasa hukum untuk pendampingan perkara. Pemberian konsultasi hukum sendiri merupakan salah satu jasa hukum advokat yang diatur dalam Undang-Undang Advokat dan Undang-Undang Bantuan Hukum, sehingga pemberian konsultasi hukum merupakan bagian dari ruang lingkup pemberian bantuan hukum.

Pengecualian penanganan perkara pada empat jenis kasus Pidana oleh PBHI Sumbar tidak selaras dengan semangat UU Bantuan Hukum dan lebih bersifat subjektif. UU Bantuan hukum hanya memberikan satu kriteria penerima bantuan hukum, yaitu miskin. Penambahan kriteria tambahan oleh PBHI Sumbar pada empat jenis kasus pidana yang dikecualikan untuk didampingi berdasarkan visi misi organisasi dan Pasal 3 huruf a KEAI mempunyai landasan hukum yang lemah. Akibatnya, Pelaksanaan bantuan hukum oleh PBHI Sumbar terbatas dan mengakibatkan tertutupnya akses orang atau kelompok masyarakat miskin dalam mendapatkan keadilan (access to justice) terutama yang berhadapan kasus pidana Korupsi, Pidana Pelanggaran HAM, Pidana Lingkungan dan Pidana seksual (asusila).

Tahap ketiga; penandatanganan surat kuasa pemohon penerima bantuan hukum yang memenuhi kualifikasi penerima bantuan hukum berdasarkan undangundang bantuan hukum dan memenuhi kualifikasi perkara yang dikecualikan oleh PBHI Sumbar di atas, selanjutnya menandatangani surat kuasa khusus kepada pengacara (atau tim pengacara) untuk melaksanakan penanganan kasus. Isi surat kuasa khusus tersebut adalah kesepakatan antara pengacara PBHI 
Sumbar dengan penerima bantuan hukum terkait ruang lingkup penanganan perkaranya, ada yang dari tahap penyidikan sampai dengan pemeriksaan di pengadilan, dan ada pada tahap-tahap tertentu dalam proses penanganan perkara pidana.

Penanganan perkara pidana pada tahap-tahap tertentu tersebut biasanya berkaitan dengan status hukum penerima bantuan hukum dalam proses penanganan perkara pidana yang sedang dijalaninya, yang umumnya telah menjadi tersangka dan telah menjalani proses penyidikan oleh Kepolisian. Pada prinsipnya pendampingan bantuan hukum tersebut berdasarkan keinginan penerima bantuan hukum untuk didampingi, baik secara keseluruhan proses penanganan kasus atau sebahagian saja yang kemudian dituangkan dalam surat kuasa khusus sebagai dasar pengacara PBHI dalam menangani perkara.

PBHI Sumbar menyebutkan bahwa pelaksanaan bantuan hukum oleh organisasinya dirasa masih terbatas, karena terkait dengan pagu anggaran yang tersedia masih minim. Pada tahun 2016, pagu anggaran bantuan hukum yang diberikan oleh Kantor Wilayah Kementerian Hukum dan HAM Sumatera Barat kepada PBHI Sumbar berjumlah Rp. 95.970.000-, (Sembilan puluh lima juta Sembilan ratus tujuh puluh ribu rupiah) yang dibagi atas dua peruntukan, yaitu litigasi, termasuk perkara pidana, perdata dan tata usaha negara dan non litigasi, untuk perkara litigasi dianggarkan sebesar Rp. 80.000.000,- (delapan puluh juta rupiah) untuk 16 orang masyarakat miskin yang mengalami permasalahan hukum, sedangkan untuk non litigasi dianggarkan sebanyak Rp. 15.970.000,(lima belas juta sembilan ratus tujuh puluh ribu rupiah). Akibatnya, PBHI perlu melakukan seleksi pelaksanaan bantuan hukum bagi warga miskin, yaitu dengan memprioritaskan warga miskin yang dirasa paling membutuhkan.

\section{Litigasi Perkara Pidana}

Dalam tingkat penanganan litigasi kasus pidana, tulisan ini mengambil dua studi kasus berdasarkan kategori sebagai berikut; pertama kasus pidana khusus dengan nomor perkara PDM14/Epp.2/Padang/08/2016. Kasus pidana khusus tersebut terkait dengan pidana anak. PBHI Sumbar melaksanakan penanganan perkara pidana anak dengan mengikuti langkah-langkah prosedur peradilan pidana yang diatur dalam UU Nomor 11 tahun 2012 tentang Sistem Peradilan Pidana Anak (yang selanjutnya ditulis dengan UU SPPA). UU SPPA mengatur tentang pengutamaan keadilan restoratif dalam kasus-kasus yang melibatkan anak. Keadilan restoratif sendiri adalah penyelesaian kasus pidana dengan melibatkan pelaku, korban, keluarga pelaku atau keluarga korban dan pihak terkait dalam mencari penyelesaian adil dengan menekankan pada pemulihan kembali. Pelaksanaan keadilan restoratif berlaku dari tahap penyidikan, penuntutan pidana anak dan persidangan anak yang dilaksanakan dengan upaya diversi.

PBHI Sumbar mengutamakan upaya diversi pada setiap tahapan sistem 
Febtrina Sari: Pelaksanaan Bantuan Hukum Pada Perkara Pidana...

peradilan pidana anak. Upaya tersebut selalu disampaikan secara lisan kepada pihak-pihak berperkara. Upaya diversi yang dimaksud hingga saat ini belum ada yang tercapai, hal tersebut dikarenakan beberapa pertimbangan yang harus ada dalam setiap proses tahapan.

Selanjutnya, PBHI Sumbar selalu mengedepankan kepentingan terbaik anak yang pada dasarnya merupakan bagian dari semangat diversi. PBHI Wilayah Sumatera Barat mengedepankan kepentingan pendidikan anak-anak yang berhadapan dengan hukum harus sekolah, hal ini dilakukan dengan cara mengirimkan surat ke beberapa instansi pendidikan dan ke para penegak hukum terkait pelaksanaan kepentingan Pendidikan anak-anak tersebut.

Pada studi kasus kedua, pemberian bantuan hukum kepada masyarakat miskin yang melakukan tindak pidana umum, PBHI Sumbar dalam menangani kasus pidana umum ini mengacu kepada ketentuan peraturan hukum acara pidana. Pemberian bantuan hukum kepada masyarakat miskin dalam perkara pidana, bisa dalam status tersangka, terdakwa, atau terpidana. Layanan bantuan hukum tersebut dapat dimulai dari tingkat pertama, upaya hukum biasa, dan atau upaya hukum luar biasa. UU Bantuan hukum mengamanatkan kepada setiap pemberi bantuan hukum dalam memberi bantuan hukum melakukan: Pembuatan surat kuasa; Gelar perkara untuk mendapatkan masukan; Pemeriksaan dan pembuatan seluruh kelengkapan dokumen yang berkenaan dengan proses penyidikan, penuntutan, dan/atau pemeriksaan di persidangan; Pendampingan pada tahap penyidikan, penuntutan dan/atau pemeriksaan di persidangan; Pembuatan eksepsi, duplik, dan pledoi guna kepentingan penerima bantuan hukum; Penghadiran saksi dan/atau ahli; Upaya hukum banding, kasasi, dan peninjauan kembali sesuai dengan permintaan bantuan hukum dan atau; Tindakan hukum lain yang sesuai dengan ketentuan peraturan perundangundangan.

\section{SIMPULAN}

PBHI Sumbar melaksanakan bantuan hukum dalam perkara pidana di kota Padang atau pada Wilayah Hukum Pengadilan Negeri Klas 1 A Padang berdasarkan UU Bantuan Hukum. PBHI Sumbar melakukan seleksi penerima bantuan hukum berdasarkan aturan normatif dalam ketentuan dan syarat penerima bantuan hukum dalam UU Bantuan Hukum, yaitu orang atau kelompok masyarakat miskin. Namun, PBHI Sumbar memiliki kategori lain dalam menentukan penerima bantuan hukum, yaitu adanya pengecualian pemberian bantuan hukum pada kasuskasus Korupsi, kejahatan lingkungan, pelanggaran HAM (bagi pelaku) dan kejahatan asusila yang dilakukan oleh orang dewasa. Pengecualian pemberian bantuan hukum ini bersifat subjektif sehingga membatasi akses penerima bantuan hukum. Selain itu, pada kasus perkara anak, PBHI belum maksimal mengupayakan upaya diversi untuk memastikan hak anak dalam konteks 
restorative justice. Dalam hal lebih umum, PBHI Sumbar masih terkendala melaksanakan bantuan hukum akibat minimnya pembiayaan kasus dari Pemerintah dan kendala-kendala administratif pelaporan kasus yang perlu adanya peningkatan kapasitas.

\section{DAFTAR PUSTAKA}

Adnan Buyung Nasution, 1982, Bantuan Hukum di Indonesia, Lembaga Penelitian, Pendidikan, dan Penerangan Ekonomi dan Sosial (LP3ES), Jakarta.

Bambang Sunggono, 2006, Metodologi Penelitian Hukum, Rajagrafindo Persada, Jakarta.

Frans Hendra Winarta, 2000, Bantuan Hukum; Suatu Hak Asasi Manusia Bukan Belas Kasihan, PT Elex Media Komputindo Kelompok Gramedia, Jakarta. ,2009, Pro Bono Publico; Hak Konstitusional fakir Miskin Untuk Memperoleh Bantuan
Hukum, PT Gramedia Pustaka Utama, Jakarta.

Ishaq, 2010, Pendidikan Keadvokatan, Sinar Grafika, Jakarta.

Jandi Mukianto, 2017, Prinsip dan Praktik Bantuan Hukum di Indonesia, Kencana, Depok.

Lexy Maleong, 1991, Metode Penelitian Kualitatif, Remaja Rosdakarya, Bandung.

Mohammad Taufik Makarao, Letkol Sus, Weny Bukamo dan Syaiful Azri (2013) Hukum Perlindungan Anak dan Penghapusan Kekerasan Dalam Rumah Tangga, Rineka Cipta, Jakarta.

Yesmil Anwar dan Adang (2009) Sistem Peradilan Pidana; Konsep, Komponen, \& Pelaksanaannya Dalam Penegakan Hukum di Indonesia, Widya Padjajaran

http://bappeda.padang.go.id/v2/index.php/ profil-daerah/geografis-kota-padang diakses tanggal 16 Oktober 2017. 